\title{
SURRENDERED HUMAN
}

\section{The path to redemption.}

\section{BY DEBORAH WALKER}

$\mathrm{I}$ 'm meditating in my room when Andrew bursts in (without knocking) and shouts out: "Guess what, Emma. There's a rumour that Mo-Sal will appear at the confirmation ceremony tomorrow."

"You've got to be kidding me." Mo-Sal: the commander of this colony. I begin to tremble.

"Just imagine," says Andrew, "breathing in his actual scent."

"It'd be overwhelming," I say. The synthetic amines that swirl around this lunar centre, the scent of ginger musk is so powerful. I shudder, as I imagine breathing in the real thing. "I don't know what to say."

"I know." Andrew flops onto my bed and stretches his arms above his head. His T-shirt rises up, exposing a swathe of taut stomach etched with a line of coarse blonde hairs. A small part of me acknowledges this, but most of me is thinking about Mo-Sal.

A thousand of us dressed in red, the colour of surrender. Today, we confirm our allegiance. Today, we will be assigned our roles. Tomorrow, we will be shipped out to a place in the Arium Domain.

The air is electric. All thoughts turned to Mo-Sal.

"Do you think he'll come?" asks Andrew. Andrew had been the comm officer on my ship. In another life we'd been close, and something of that still remained.

"I respect his decision," I say. Actually, I am willing him to come. To see him. To actually breathe in his scent. How wonderful that would be. I guess we're all thinking that, or most of us, at least. Humans are a poor species, driven by personal desires. I feel ashamed.

"It's all right, Em," says Andrew. "I understand."

I smiled. He was good to me. We were good together, once.

On the stage, the drums begin to beat. And we, we thousand surrendered supplicants, chant the words. I've been longing for this moment for six months, ever since my ship was captured. To think that I'd actually initiated the destruction sequence. It seems impossible that I'd been so resistant. We shouted the joyous words:

"We will surrender control to the Arium.

"We will accept our

$\rightarrow$ NATURE.COM

Follow Futures:

y @NatureFutures

f go.nature.com/mtoodm places in the community of the Arium Domain.

"We will be grateful."

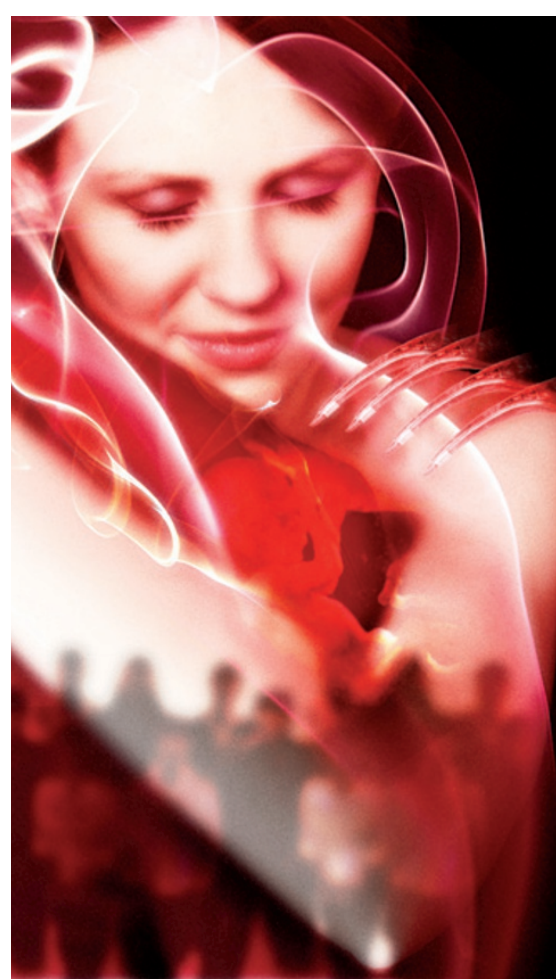

Grateful. The quality of gratitude fills me, lifts me beyond my lower self. I am so grateful.

I walk up to the podium, when my name is called.

"Emma Catell, former captain of the Earth ship, The Entangled Hope."

I wince at the reminder of my previous life. To think I had been so arrogant as to seek to control the Arium. But there is no shame here. I know that because as I am holding out my hand to receive my assignment, something wondrous happens. A portal opens, a rip in space. Mo-Sal steps through the anomaly and onto the platform. His overwhelming scent. I sway on my feet. I see others falling to the floor. Mo-Sal is so powerful, but I have always had a quality of will, and I remain on my feet. I take no pride in that, it is a fault that led me to my previous actions, but all is forgotten here.

Mo-Sal lays his claw on my shoulder. I feel a wave of peace. I know that this is the defining moment of my life.

"You are Emma Catell." His dry-rasping words are resonant, portentous. He is all things. "You are the Earth captain responsible for one hundred and thirty-five Arium deaths."

I hang my head in shame.

"You are surrendered."
"I am, Mo-Sal."

"You have done well."

"Thank you," I whisper, remembering to receive a compliment graciously, but it is so difficult. I want to prostrate myself. I am an embarrassment.

"You will work on the surrendered Earth with the delinquents." Another reason for shame - some human have atrophied vomeronasal organs. They are unable to experience the chemical communion of the Arium. They are resisting the natural order of things.

"Thank you, Mo-Sal." This task is not what I hoped for. I would have liked to have served in the Arium Navy, bringing enlightenment to other worlds, but I gladly relinquish my personal desires and trust in Mo-Sal.

As Mo-Sal moves, a plume of his scent assaults me. I moan.

He touches me delicately on the chin. "Do not be ashamed, Emma Catell. You must embrace this." How kind he is. How much he understands.

I walk back to my place in the crowd. I glance at Andrew but his eyes and his thoughts are fixated on Mo-Sal, as mine should be.

As the ceremony proceeds, I think about Mo-Sal's words. I believe that he has given me a task. Species surrendered to the Arium often wither within a few generations. The desire for reproduction is subsumed in the love of the Arium. This is wrong. I want humans to serve the Domain for generations, stretching into the future. I will take the human approach in my new life. This is the task Mo-Sal has given me. I glance at Andrew.

The ceremony continues, until we're all assigned. Yet even in this moment of peace and wonder, there is a worm in my mind, an unwelcome remnant of my past self.

This is all biochemical, says the worm, whispering its vile thoughts. This is control. Mere biological control.

I am a great sinner, yet I'm filled with gratitude. This resistance inside of me is a gift. It means that I'll struggle for redemption. My subservience will be real and meaningful.

I whisper a prayer to the Arium for the opportunity to struggle in their honour. I breathe in the heady scent of Mo-Sal's musk. .

Deborah Walker grew up in the most English town in the country, but she soon high-tailed it down to London where she now lives with her partner, Chris, and her two young children. 